in the baby were related to a noxious agent in the milk. Indeed, the whole picture suggests that the basis is one of over-anxiety. Colonic spasm is likely to be the cause of the left-sided pain and to give rise to occasional right-sided pain from the caecum. The abdominal discomfort has probably always been of bowel origin, and the ovary which was removed was blameless. The general disturbance associated with menstruation represents exaggerated molimina, amounting to what is sometimes called a "menstrual tension state," which again often has a psychological underlay. Night sweats, sometimes most profuse and disturbing, are common enough during the puerperium and early weeks of lactation, and in the absence of pyrexia they are not of any real significance. Persistence of red lochial discharge for six weeks after delivery is also not necessarily pathological. Cyclical ulceration of the mouth associated with menstruation and perhaps causing discomfort in the gums is a condition the cause of which is unknown. It may be an allergic manifestation, and is dealt with at some length in replies to questions in the Journal (Aug. 21, 1948, p. 408 ; March 15, 1947, p. 365; and June 15, 1946, p. 940).

\section{Paroxysmal Tachycardia}

Q.-A male aged 73 has suffered from paroxysmal tachycardia for nearly 20 years, and the attacks seem to be increasing in frequency-though not in intensity. Treatment with quinidine appears to have little effect. Is there any other treatment that would decrease the number of paroxysms or abort or shorten the attacks?

A.--If quinidine in doses of 5 gr. $(0.32$ g.) thrice daily has failed to influence the frequency or duration of the attacks, mepacrine $0.1 \mathrm{~g}$. daily may be tried when attacks are particularly frequent. Although digitalis is usually contraindicated, it is helpful occasionally, and is always worth trying when other methods fail.

\section{NOTES AND COMMENTS}

Anaesthetics for Domiciliary Midwifery.-Dr. J. E. M. Barnes (Eye, Suffolk) writes: I was interested in the answer to the question, about anaesthetics in domiciliary midwifery ("Any Questions?" July 9 , p. 112). It was stated that the Cyprane inhaler could be adjusted to produce a concentration of "trilene" sufficient for general anaesthesia. I would like to know whether this was a theoretical assumption or based on practical experience. I have used one of these inhalers with complete satisfaction in purely domiciliary surroundings-but only in so far as analgesia is concerned. On occasion I have tried to induce anaesthesia, but not successfully. In cne particular case forceps blades were positioned on the foetal head without untoward reaction, but as soon as traction occurred the patient resisted the manœuvre. - It was a low-forceps delivery, and was terminated rapidly and smoothly, with no difficulty, after anaesthetizing with straight chloroform. I would be interested to know from others their experiences in this particular direction, because I am loath to follow trilene with chloroform as a routine having, since the case quoted, run up against an alarming instance of cardiac arrest due presumably to vagal inhibition, which entailed resuscitation of mother, infant (white asphyxia), and, almost, the single-handed G.P.

Weight in Pregnancy.-Dr. F. R. KinKead Allén (Belfast) writes: Gain in weight during normal pregnancy ("Any Questions?" May 7, p. 831) is subject to rather wide variation. In the United States of America this gain appears to be more than in the British Isles. According to McIlroy and Rodway (J. Obstet. Gynaec. Brit. Emp., 1937, 44, 221), in a thousand cases the average total gain among primiparae was $11 \mathrm{lb} .3 \mathrm{oz}$. $(5 \mathrm{~kg}$.) and for multiparae it was $11 \mathrm{lb} .7 \mathrm{oz} .(5.2 \mathrm{~kg}$.), and they noticed that the older patients gained less in weight than the younger ones. According to Chesley (Amer. J. Obstet. Gynec., 1944, 48, 565) the average gain in weight may be generally ranked as $24 \mathrm{lb}$. $(10.8 \mathrm{~kg}$.) ; two-thirds of the normal women in his series gained between 18 and $35 \mathrm{lb}$. (8.1 and $15.7 \mathrm{~kg}$.), but one-sixth gained more than $35 \mathrm{lb}$. $(15.7 \mathrm{~kg}$.). The total increase in any one case, however, is to some extent dependent on the woman's initial bulk, and Stander and Pastore (Amer. J. Obstet. Gynec., 1940, 39, 928) suggest that it should not exceed $25 \%$ of the pre-pregnancy weight. There are, however, many exceptions even to this, and gain does not take place regularly throughout pregnancy. In the first three months there is often little gain, and even a loss may be recorded, especially where a woman suffers from vomiting or anorexia. In the last two or three weeks there may also be a tendency to lose or to cease to gain weight. McIlroy and Rodway claim to have prevented the onset of toxaemia in patients showing excessive gain in a week by regulating diet and by increasing walking exercise. Emblin (British Medical Journal, 1949, 1, 260) 'considers that the weekly gain during pregnancy should not exceed $8 \mathrm{oz}$. $(0.22 \mathrm{~kg}$.).

Bacteriology of the Throat.-Dr. W. B. Orme (Hove, Sussex) writes: One of the queries in "Any Questions?" (July 2, p. 39) was, "What is the normal bacteriology of the throat ?" In answering, your specialist replied giving non-haemolytic streptococci of the viridans and salivarius types, Gram-negative diplococci of the catarrhalis group, slender Gram-negative bacilli of the Haemophilus influenzae family, and Gram-positive diphtheroids. Further on in his reply he refers to organisms which are recognized as pathogens, including Staphylococcus aureus, haemolytic streptococci, pneumococci, meningococci, and occasionally diphtheria bacilli. Not in the whole reply does he once mention the well-known Friedländer's bacillus, also known as Bacterium mucosum-capsulatum and other names; micro-organisms of this grcup are not infrequently associated with various respiratory infections in man, though in many cases these are considered as being simple secondary invaders. Yet they are commonly present in the nasopharynx of patients suffering from chronic sinusitis, and in some cases they are definitely pathogenic, accounting for $1 \%$ of all pneumonias-such cases have an exceptionally high case-fatality rate. Again, Friedländer's bacillus is one of the most difficult organisms to deal with, as it appears to be resistant to all modern bacteriostatic drugs. I am therefore surprised at its omission from your reply.

Ergotamine and Pregnancy.-Dr. K. D. Salzmann (Reading) writes: Your answer to the query on ergotamine and pregnancy ("Any Questions?" July 2, p. 40) states that, "unless the patient's previous history suggests a special susceptibility to abortion or premature labour, ergotamine is unlikely to have any significant effect on the uterus, and its continued administration is therefore not contraindicated." A few years ago a consultant recommended to one of my colleagues a simple method of inducing labour. He advised giving one ergometrine hydrochloride tablet every morning until labour ensued. My colleague, at his next antenatal clinic, found three of his patients were about a fortnight postmature and unfortunately decided to try the ergometrine method of induction. It worked. All three mothers went into labour within three days. All three had spontaneous labours, and all three gave birth to macerated foetuses, although at the last antenatal examination the infants were alive. In addition to the above experience $I$ recall a patient of mine who had reached term and developed a migrainous headache. I gave her a tablet of ergotamine tartrate. She started in labour, had violent pains, and gave birth-spontaneously - to a stillborn infant. In view of the experiences of my colleague and myself I think one should say that it is unwise to give ergotamine to a primigravida in the early months of pregnancy (before it is known whether she has any tendency to miscarriages) and rarely or never should it be given when the uterus is no longer inert-at term or during the last few weeks preceding maturity. There is one exception to the above rule. If the foetus in utero is dead, one might utilize the daily tablet of ergometrine or ergotamine as a means of inducing labourparticularly if massive oestrogen therapy has failed. I have known this done successfully on several occasions.

\section{Corrections}

Dr. E. K. Pritchard (Southwark) writes: It is not clear in the report of my remarks at the Commonwealth and Empire Tuberculosis Conference (July 16, p. 152) that domiciliary collapse therapy was first organized on a large scale in May, 1946, by $\mathrm{Dr}$. C. H. C. Toussaint and myself in our respective Boroughs of Bermondsey and Southwark. Dr. Toussaint subsequently organized a similar scheme in the Borough of Willesden. The necessity for this form of treatment was the natural corollary of the success of the mass $x$-ray survey of cases with minor respiratory symptoms started in similar collaboration between Dr. Toussaint and myself in 1942. This survey brings to light a large number of early cases in urgent need of treatment.

The Hunterian Lecture by Dr. W. S. C. Copeman, published in the Journal of July 23 (p. 191), was incorrectly described as the Hunterian Oration.

All communications with regard to editorial business should be addressed to $T_{H}$ EDITOR, BRITISH MEDICAL JOURNAL, B.M.A. HOUSE, TAVISTOCK SQUARE, LONDON, W.C.1. TELEPHONE: EUSTON 2111. TELEGRAMS: Aitiology Westcent, London. ORIGINAL ARTICLES AND LETTERS forwarded fo publication are understood to be offered to the British Medical Journal alone. Authors desiring REPRINTS should communicate with the Publishing Manager. B.M.A. House, Tavistock Square, W.C.1, on receipt of proofs.

ADVERTISEMENTS should be addressed to the Advertisement Manager. B.M.A. House, Tavistock Square. London, W.C.1 (hours 9 a.m. to 5 p.m.) TELEPHONE: EUSTON 2111. TELEGRAMS: Britmedads, Westcent. London. MEMBERS' SUBSCRIPTIONS should be sent to the SECRETARY of the Association. TelePhONE: EUSTON 2111. Telegrams : Medisecra, Westcent Iondon.

B.M.A. SCotrish OFFICE: 7, Drumsheugh Gardens, Edinburgh 